A RELIC OF ANCIENT MEXICO.

THE appearance of No. I of the Peabody Museum Papers marks a new departure in the publications of the Museum of American Archæology and Ethnology. Henceforth, Prof. F. W. Putnam states, the special papers, hitherto published in connection with the Annual Reports, will be issued in a separate but similar octavo form at irregular intervals, as the means for printing them is obtained. Part I of vol. i. of this new series, just received, consists of an interesting and thoughtful historical essay on a relic of ancient Mexico entitled "Standard or Headdress," by Mrs. Zelia Nuttall, accompanied by three coloured plates. A quarto German translation by Dr. A. B. Meyer appeared in the last volume of the Abhandiungen und Berichte des K. Zoologischen und Anthropologisch-Ethnographischen Musezums zu Dresden. It treats mainly of a remarkable piece of ancient Mexican feather-work inlaid with gold of the time of Montezuma, which was one of the first presents received and forwarded by Cortes to the Emp ror Charles V. It subsequently formed part of the famous Ambras collection of historical armour, figuring in various catalogues of that collection as a "Moorish hat," an "Indian apron," and a "Mexican head dress," and is now preserved in the Imperial Natural History Museum of Vienna. It was carefully restored by the late Prof. F. von Hochstetter, who published in 1884 a description of it as a "banner" or "fanshaped standard," basing this identification chiefly upon the resemblance it presented to a "fan-shaped object" depicted behind the portrait of a Mexican warrior in the "Bilimek" collection acquired by the Museum in 1878 . In the present essay Mrs. Nuttall adduces abundant testimony that the feather piece in question was a head-dress which formerly presented all the attributes of colour, form, and insignia of the war-god Huitzilopochtli, the hero-god and totemic divinity of the Mexicans. Such head-gear could have been worn only at the time of the conquest by Montezuma, "the living representative of the god," as "supreme pontiff and chief warrior." An exactly similar emblematic head-dress, she points out, is depicted on the so-calied "sacrificial stone" as worn by Jiz-oc, one of Montezuma's predecessors. It is further maintained that the painting of the "Bilimek" warrior must be regarded as a rebus and not as a portrait. The "fan-shaped object" is the insignia of Quetzal feathers, characterizing the high rank of the warrior, who was also a priest, and is represented as clad in a human skin. The house $=$ calli, piece of cord $=$ mecat $l$, and arrows $=$ tlacocht $l$, s milarly depicted,yield, together with the Quetzal feather insign:a when deciphered with the aid of the associated complementary sign, the phonetic values: (1) the surname Calmecahua; (2) the title Tlacochcalcatl $=$ lord of the house of arrows or supreme war-chief; and (3) the tribal designation Quetzalapanecatl, a native of Quetzalapan, a locality near Mexico conquered by the Mexicans in $15 \mathrm{I}_{2}$. This renders probable the identification of the individual as that Calmecahua, or lord of the ca'mecac, who, as Diaz relates, "fought like a lion on the side of the Spaniards" at $\mathrm{th}$ 2 battle of Otumba against his natural foes the Mexicans, and was afterwards baptized as Don Antonio, and is cited by Txtlilxochitl as the author of a history of Tiaxcala, written in 1548. However this may be, it is evident that he was a pilhua, or head of a large family, as Mrs. Nuttall shows that the heads, surmised by Dr. Hochstetter to be those of "decapitated enemies," painted at his feet, are the usual signs for enumerating individuals, by reference to other Mexican manuscripts extant, in which similar heads under a figure are accompanied by the Nahualtl word for genealogy, and in the case of a manuscript dating about 1520 , in the possession of Mr. Bernard Quaritch, by the Nahuatl text in Spanish letters = "Tenancacaltzin these his sons' heads." In an appendix to this suggestive paper Mrs. Nuttall discusses the complementary signs of the Mexican graphic system.

\section{SCIENTIFIC SERIALS.}

Bulletin de l'Académie K'oyale de Belgique, October 1888.-On the influence of diurnal nutation in the discussion of the observations of $a$ Lyræ, made at the Washington Observatory, by $L$. Niesten. In these researches, which are somewhat analogous to his previous observations on $\gamma$ Draconis made at Green wich, the author adduces a fresh proof of the existence of diurnal nutation. The coefficient resulting from his determination is $0.095^{\prime \prime}$, giving $69^{\circ}$ east of Paris as the longitude of the first meridian.-On a new registering process by means of photography, by Eric Gérard. In this ingenious apparatus, instead of using the voltaic arc as the source of the light falling on the concave mirror whose movements have to be recorded, the inventor employs the secondary spark supplied by the Ruhmkorff bobbin. This spark being periodical, owing to the elasticity of the check-spring of the bobbin, naturally gives the division of time in equal intervals inscribed on the registering curve. In this way the use of all special chronographs may be dispensed with. The author has applied the method to the study of the variable currents supplied by dynamos with alternate currents, and has obtained excellent results.-Jean Masius contributes a memoir on the genesis of the placenta in the rabbit, with a view to the elucidation of the difficult questions connected with the origin and purpose of various elements present in the fully developed placenta.

Rivista Scientifico-Industriale, November 15, I888. -Granular snow and the theory of the formation of hail, by Prof. Ferdinando Palagi. The author had a good opportunity of studying the phenomenon of granular snow during a heavy snow-storm at Teramo on October 20. 'The grains, about the size of ordinary peas, were perfectly dry, falling with a clatter like that of hail, which they resembled somewhat in appearance, although evi. dently formed, not by superimposed layers of ice, but by particles of snow agglomerated under certain atmospheric and perhaps electrical conditions. They were relatively light, perfectly white and opaque, yielding under pressure between the fingers, and from their general appearance and the circumstances of their formation Prof. Palagi concluded that granular snow is the first phase in the formation of hail. $\rightarrow$ On the development of electricity from the evaporation of marine water under the exclusive action of the solar rays, by Prof. Luigi Palmieri. Some recent experiments with the Bohnenberger electroscope are here described, which fully confirm the conclusions already arrived at forty years ago by the author, and in fact anticipated by Volta, regarding the origin of atmospheric electricity from aqueous evaporation.-Signor Giuseppe Terrenzi describes some remains of the beaver (Castor fiber, Lin.) lately discovered in the Pliocene formations of the Colle dell' Oro near Terni.

\section{SOCIETIES AND ACADEMIES. \\ LONDON.}

Linnean Society, December 20, 1888.-Mr. W. Carruthers, F.R.S., President, in the chair.-Prof. R. J. Anderson exhibited a photograph of an apparatus for the microscope which he had designed, consisting of a revolving disk with clips, by means of which a number of slides may be successively brought opposite the microscope, which is fixed in a horizontal position in front of it.-Mr. Clement Reid exhibited fruit of the Hornbeam from the pre-glacial forest bed at Pakefield, near Norwich, and not previously recorded as occurring in any British deposit. - Mr. 'T Christy exhibited a collection received from Java of hairs from the base of various ferns, notably Cibotium Cummingii, and a species, as supposed, of Dicksonix, used as a styptic, for staunch. ing blood. Prof. Stewart, in pointing out that the use of similar material for a like purpose in China was well known to surgeons, took occasion to explain the nature of the so-called "lamb of Tartary," on which an instructive little volume had been published by the late Mr. Henry Lee, F.L.S. Mr. D. Morris remarked that the use of "fern hairs" was also known as a styptic in South America, whence specimens had been forwarded to the Herbarium at Kew.-A paper was then read by Mr. D. Morris on the characteristics of plants included under Erythroxylon Coca, Lamarck, with a description of a new variety, which he proposed to name, from its origin, $E$. noz . granatense. $\mathrm{He}$ pointed out that the well-known coca-plant had been noticed by botanists and travellers for the last 300 years; and that, although Clusius was generally regarded as the earliest writer on it, he had been anticipated by Nicholas Monardes in his "Historia Medicinal," published at Seville in 1580, and translated by Clusius, who printed it in a condensed form in his "Exoticorum libri decem " in I605. The plant was first described as a species by Lamarck, in the "Encyclopédie Méthodique" in 1786, from specimens brought by de Jussieu from Peru. Until lately the leaves had been used merely as a nervous stimulant, like opium in China, and betel in the East Indies; but had latterly come into prominence as the source of cocaine, a valuable alkaloid possessing anæsthetic properties in contact with the mucous membrane. There were several climatic forms more or less distinct; and after describing the typical plant, Mr. Morris pointed out the characters by which E. novo-granatense might he distinguished. The paper was ably criticized by Mr. J. G. Baker, Mr. Rolfe, and Mr. Thomas Christy.-Mr. Spencer Moore 